\title{
Extraterritorial human rights obligations and international financial institutions
}

\author{
Stéphanie de Moerloose, Gamze Erdem Türkelli \\ and Joshua Curtis
}

\section{Introduction}

International Financial Institutions (IFIs) are international institutions that provide public financing for development policies, projects, programmes or macroeconomic policy. IFIs comprise global and regional multilateral development banks (MDBs) such as the World Bank Group (WBG), ${ }^{1}$ the European Investment Bank, the European Bank for Reconstruction and Development (EBRD), the African Development Bank (AfDB), the Asian Development Bank (ADB) and the Inter-American Development Bank (IADB). The development financing also includes so-called development finance institutions (DFIs) of developed states that work principally but not exclusively on a bilateral basis, where a state is either the sole or majority shareholder. In addition, macroeconomic policy institutions such as the International Monetary Fund (IMF) are considered to fall under the umbrella.

The various positive and negative effects on human rights resulting from the policies and practices of IFIs have been deliberated since the 1990s within academia, United Nations (UN) human rights mechanisms and beyond, most often in the context of economic, social and cultural rights and increasingly through the lens of extraterritorial human rights obligations. This debate has been enriched by human rights scholars' and practitioners' increasing engagement with global finance (Dowell-Jones and Kinley 2011; Nolan 2016), sovereign debt (Bohoslavsky and Letnar Cernic 2014; Bantekas and Lumina 2018), austerity policies (Krajewski 2014; Salomon 2015; Warwick 2018) and numerous other aspects of IFI conditionality and structural adjustment (Kentikelenis et al. 2016; Stubbs and Kentikelenis 2018). Of note, an initial legaldoctrinal focus on the relationship between IFIs and human rights has been productively complemented over time with the integration of broader, contextually driven political economy and governance perspectives (Salomon 2007; von Bogdandy et al. 2010; Evans 2011; De Schutter 2012; Augenstein 2014). This is especially welcome given the centrality of IFIs to the global economic order and its governance, which increasingly determines the prospects for human rights realisation in every state. The dominance of economic norms over human rights norms is a recurrent and key theme in this, now extensive, body of work, as is the manner in which international law is (ab)used to constrain the effectiveness and development of the latter set of norms in favour of enhanced protection, enforcement and incentivisation of the former set. 
Conceptually, human rights obligations beyond borders (for the sake of brevity, Extraterritorial Obligations (ETOs)) related to IFIs may be defined along two main axes. The first axis is state obligations as members and owners (shareholders) of IFIs. The second axis centres on the human rights obligations of IFIs themselves. This chapter first takes stock of ETOs of states when they are members and shareholders of IFIs and then moves on to explore the human rights obligations of IFIs directly under international law. Subsequently, the chapter looks into the question of human rights accountability of IFIs, both internally and externally. Finally, the chapter draws general conclusions and takes a forward-looking perspective and assesses the normative development of ETOs related to IFIs under international law.

\section{States as members and shareholders of IFIs}

The basic principle that states retain the full range of their human rights obligations as members of international organisations (IOs), including IFIs, has been reiterated in various General Comments (GCs) of UN treaty bodies. The UN Committee on Economic, Social and Cultural Rights (CESCR) in its GC 3 on the nature of states parties' obligations notes that under international law 'international cooperation for development and thus, for the realization of economic, social and cultural [(ESC)] rights is an obligation of all states. It is particularly incumbent upon those states which are in a position to assist others in this regard' (1990b, para. 14). CESCR has underscored that states have obligations of international assistance and cooperation for the realisation of ESC rights, particularly with respect to development projects and debt relief (CESCR 1990a, para. 8; CESCR 1990b, para. 14). CESCR's statement on the COVID-19 pandemic and ESC rights underscores that states 'should ... use their voting powers in [IFIs] to alleviate the financial burden of developing countries in combating the pandemic, with measures such as granting these countries different mechanisms of debt relief' (CESCR 2020, para. 21).

Substantive rights such as rights to health, to water, to work, to just and favourable working conditions and to social security should be 'taken into account' when states 'influence the lending policies, credit agreements and international measures' of IFIs, particularly referring to the WBG and the IMF (CESCR 2000, para. 39; 2002, para. 36; 2005, para. 30; 2008, para. 58; 2016, para. 71). Even more strongly, CESCR's GC 23 on the Right to Just and Favourable Working Conditions holds that states as members of IFIs 'should ensure that the policies and practices of international and regional financial institutions, in particular those concerning structural and/or fiscal adjustment, promote and do not interfere with the right' (2016, para. 71). CESCR's concluding observations have also called on developed countries to ensure that the actions of IFIs of which they are members and shareholders do conform to ESC rights obligations (Khalfan 2017). State duties to uphold ESC rights also hold when the IFIs of which they are members are architects of structural adjustment and austerity policies to be implemented in third states (CESCR 2002, para. 36). Similarly, Principle 15 of the Maastricht Principles on Extra-Territorial Obligations of States (The Maastricht Principles) underscores that states remain 'responsible for [their] own conduct in relation to [their] human rights obligations within [their] territory and extra-territorially' as members of IOs. In line with CESCR's relevant GCs, when states 'transfer[.] competences to, or participate[.] in, an [IO]', they 'must take all reasonable steps to ensure that the relevant organisation acts consistently with' its human rights obligations. Similarly, Principle 10 of the UN Guiding Principles on Business and Human Rights (UNGPs) notes that member states of IFIs (and other multilateral institutions working on business-related areas) should '[s] eek to ensure that [they] neither restrain the ability of their member states to meet their duty to protect nor hinder business enterprises from respecting human rights; [and] [e]ncourage [them], within their respective mandates and capacities, to promote business respect 
for human rights and, where requested, to help States meet their duty to protect against human rights abuse by business enterprises, including through technical assistance, capacity-building and awareness-raising' (UN HRC 2011).

The relative weight of different state members in the decision-making structures of IFIs and thus their ability to 'ensure' the respect for, protection of and fulfilment of human rights obligations when they participate in IFIs or confer competences to them, differ wildly. Yet, the conceptual legal debates on the attribution and distribution of human rights obligations to states as members of IOs and IFIs have not distinguished between states or argued for differentiated obligations on the basis of how they impact decision-making processes within these institutions, including shareholding, voting and ownership structures. Comparable to the position of multinational companies that can exercise their leverage in their supply chains in order to incentivise the observance of human rights, certain member states of IFIs have the possibility - by virtue of their voting or economic power - to wield greater influence within these institutions and could deploy such influence to promote respect for and protection of human rights by IFIs.

Much of the work on state obligations with respect to human rights beyond borders when they participate in IFIs and the obligations of IFIs themselves has focused on conceptualising what Tan terms 'rights compliance - refraining from interfering directly or indirectly with the right in question or preventing third party interference with such a right' (Tan 2008, p. 84). The legal questions around attribution and distribution of duties and thus of responsibility for violations among states as members/shareholders of IFIs and IFIs themselves have thus taken place in the context of legal responsibility. That process has been particularly influenced by the International Law Commission's Articles on State Responsibility for Internationally Wrongful Acts (ARSIWA) and Articles on the Responsibility of International Organisations (ARIO). Accordingly, IOs as international legal persons, including IFIs, bear direct responsibility under international law for the breaches of their international legal obligations. Consequently, the legal responsibility of member states for the breaches resulting from IO acts or omissions is treated as the exception to this rule (Ryangaert and Buchanan 2011). There are, nonetheless, arguments suggesting that responsibility of IFIs and their member states may be jointly invoked depending on the specific mandate and relationship between the member state and the IFI in question (Sarooshi 2005). Joint responsibility may entail the responsibility of the IFI for its operations while member states may retain responsibility for their involvement in the decision-making processes leading to internationally wrongful acts. It stands to reason, thus, that greater the influence a state wields and the greater its contribution to an organisation's decision-making, the greater the responsibility it should incur as a result of any wrongdoing stemming from the organisation's operations based on those decisions. In addition, states members may be responsible for the acts of IFIs if the acts fall under the powers conferred to the IFI (Sarooshi 2005).

\section{Human rights obligations and IFIs}

There is a long-lasting discussion as to whether IFIs themselves are obligated or should be obligated to comply with human rights. The debate has seen two contradictory main arguments. The first supports the obligation of IFIs to comply with and implement human rights, and the second refutes this obligation, generally based on an argument around the protection of the recipient state's sovereignty. According to the first argument, IFIs should comply with hard international law, which is legally binding for recipient states and also applies to IFIs themselves as they are IOs (Bradlow 1996). Recalling the ICJ: 'international organizations are subjects of international law and, as such, are bound by any obligation incumbent upon them under general rules of international law' (ICJ 1980, p. 73 para. 37). As IOs, IFIs are therefore generally 
recognised as also bound by norms of customary international law (Bradlow 2001; Dann 2013). A distinct case should be made of the WBG institutions, which, as specialised agencies of the United Nations, should be recognised as bound by human rights law as well (United Nations 1947; Dann 2013).

Some scholars have suggested that IFIs bear direct human rights duties under international law based on their mandates, constituent agreements and relevant international law principles (Van Genugten et al. 2003; De Schutter et al. 2012). According to Skogly (2003), IFIs bear direct obligations to respect human rights. In addition to obligations to respect, IFIs have an obligation to protect human rights in the domain of their activities and operations that is auxiliary to state obligations (Bradlow 1996). IFIs may also play a role in promoting the realisation of human rights in their member states when they finance projects and policy interventions (Bradlow 1996; McInerney-Lankford 2010). Maastricht Principle 16 notes that states' obligations as members and shareholders of IFIs do not prejudice the existence of IO obligations under 'general international law and international agreements to which they are parties'. This view is also supported by proponents of the human rights-based approach to development adopted by many development institutions (UN Practitioners' Portal on Human Rights Based Approaches to Programming). Also, as long as member states entrust IFIs with the power to create policies that respect hard and soft international law, the principle of specialty is respected (ICJ 1996, p. 226 para. 25; Dupuy and Kerbrat 2016). Echoing McBeth, IFIs should be assigned 'independent legal obligations' as they autonomously carry out various delegated functions without these functions being 'the direct result of collective State action' (McBeth 2009, p. 67).

The second argument is a direct rebuttal of the positions exposed above, as it questions the legitimacy of the implementation of human rights by IFIs, principally because it forces the recipient state to take certain measures in exchange for financing, often through the insertion of conditionality. This position has often been shared by recipient states' government and by IFIs' senior staff. This argument rests on the principle of the sovereign equality of states recognised in Article 2 of the UN Charter and in several international UN declarations, which prohibits intervention in foreign states' political affairs (Res. 2131 (XX) 1965; Res. 2625 (XXV) 1970; Res. 36/103 1981; Dann 2013; Woods 2001; Babb and Carruthers 2008). The Charters of most MDBs share this principle, prohibiting intervention in the recipient states' political affairs, through the so-called political prohibition (Killinger 2003; Shihata 1988-1989 and 1992; Naudé Fourie 2009; McInerney-Lankford 2010). This very principle supports a number of movements calling for, inter alia, the eradication of conditionality and the restructuring of IFI governance (CNN 2010; Woods 2006).

Contradicting this argument, some proponents of the recognition of direct human rights obligations by IFIs have called for a restriction of the use of the principle of sovereignty, especially when it is claimed in order to shield recipient governments from their international human rights obligations (Henkin 1999). Furthermore, sovereignty also gives the donor states the right to choose how to manage their own resources. In that sense, donor states may demand resources to be used in compliance with human rights (Dann 2013; Mosley et al. 1995). There is thus an obligation to respect the sovereignty of both parties, which can possibly be in conflict. In any case, the respect of a recipient state's sovereignty in a domain underpinned by power asymmetries is a particularly important but delicate exercise (Anghie 2000; Pahuja 2011; Escobar 1995). Indeed, recipient states are generally minority voters and IFIs are often effectively dominated by donor states. The discontent among emerging economic powers with this situation has led to the creation of the New Development Bank in 2014 and the Asian Infrastructure Investment Bank in 2015, which are controlled by these emerging economies (Dann and Dollmaier 2021), but these actors are also governed by similar structures, including political prohibitions in 
their constitutive legal documents. Finally, in addition to sovereignty, it is important to also take into account the recipient state's context for the implementation of human rights obligations within IFI activities. Although they may themselves be bound by human rights obligations and treaties, such implementation may be rendered problematic by different circumstances such as internal conflicts of interests, insuperable economic barriers, corrupt political power structures, conflicts or cultural dynamics, such as informal alternatives to formal institutions (Channell 2006, pp. 138-139).

Over the last three decades, CESCR has been addressing IFIs directly with respect to their substantive human rights obligations in its GCs under the rubric of the obligations of 'actors other than states parties' or 'non-state actors'. At a very basic level, CESCR's GCs 14, 18 and 23 note that 'the World Bank, regional development banks, the International Monetary Fund' should 'cooperate effectively with States parties in the implementation of [the rights to health, to work and to just and favourable conditions of work]' (CESCR 2002, para. 64; 2005, para. 53; 2016, para. 76). The CESCR underscores that IFIs, in particular the WBG and the IMF, should take into account and/or 'pay greater attention to the protection of' the rights to health, to water and to work in lending policies, credit and other agreements as well as structural adjustment programmes (ibid). Cognisant of the negative impact that structural adjustment programmes have in terms of the loss of public employment, the CESCR (2005) notes more strongly that 'particular efforts should be made to ensure that the right to work is protected in all structural adjustment programmes' (para. 53). In addition, the 'enjoyment of the right to social security, particularly by disadvantaged and marginalized individuals and groups, [should be] promoted and not compromised' in the work of IFIs (CESCR 2008, para. 83).

The UN Committee on the Rights of the Child (CRC Committee) (2013) also notes that '[IOs] should have standards and procedures to assess the risk of harm to children in conjunction with new projects and to take measures to mitigate risks of such harm' and 'put in place procedures and mechanisms to identify, address and remedy violations of children's rights in accordance with existing international standards, including when they are committed by or result from activities of businesses linked to or funded by them' (para. 48).

Most recently, the Guiding principles on human rights impacts assessments of economic policy reforms has underscored that IFIs 'should not exert undue external influence ... so that [states] are able to take steps to design and implement economic programmes by using their policy space in accordance with their human rights obligations' (Principle 14, footnote omitted) and 'should ensure that the terms of their transactions and their proposals for reform policies and conditionalities for financial support do not undermine the borrower/recipient State's ability to respect, protect and fulfil its human rights obligations' (Bohoslavsky 2020, pp. 1416-1417).

\section{Accountability}

\section{Internal accountability}

Generally, IFIs do not consider their activities to be directly bound by international human rights law, as explained above (Killinger 2003). However, pressure from states and NGOs has pushed IFIs to self-regulate their activities regarding human rights and sustainable development obligations (Park 2005; Houghton 2019). This has been done through conditionality, both regarding the selection of the project and then regarding its implementation. Generally, IFIs have no implementation mandate: the recipient state carries out the project and reports to the IFIs, which may provide support and shall supervise the project's implementation. Thus, the conditionality, enclosed in the contractual documents, defines what the recipient state needs to do or 
abstain from doing, in order to obtain the scheduled disbursements. This type of conditionality generally originates from the IFIs' environmental and social safeguards, the substantive instruments that integrate some human rights and other sustainable development-related concerns in IFIs, especially in MDBs. They describe the recipient state's obligations regarding environmental and social matters and can be stricter than national laws.

The safeguards vary in each IFIs, but some topics are commonly covered throughout the MDBs. Each has provisions on at least certain aspects of biodiversity and natural resources; pollution; community health, safety and security; occupational health and safety; climate change; cultural resources and heritage; indigenous peoples; land acquisition, resettlement or gender (Himberg 2015; Mbengue and de Moerloose 2017). However, these topics are dealt with differently, which marks a disparity between MDBs on the extent to which they adhere to human rights standards. For instance, the United Nations adopted the Convention on The Rights of Persons with Disabilities in 2006. However, how disability is taken into account varies amongst MDBs: the WB does include disability, the IFC expressly mentions 'physical or mental disability' to determine an individual's vulnerability, the AfDB specifically includes the 'physically handicapped' as vulnerable, while the ADB safeguards do not include disability (IFC 2012, Performance Standard 1 n18; World Bank 2017, i.a. ESS 10, para. 20;AfDB Group 2013, Operational Safeguard 1). Another example is the MDBs' list of prohibited activities. Only the AfDB prohibits investments in precious stones, pearls and gold, only the IADB bans non-compliance with workers' rights at work, only the EBRD's list does not include child labour, while the WB has no exclusion list (AfDB Group 2013, Policy Statement n5, p. 18; IADB Exclusion list; EBRD 2008). Of course, the safeguards apply in a project together with the recipient state's normative framework. By using local courts, affected populations can demand their rights be respected as recognised in the recipient state, but the courts generally cannot take the safeguards into account. It is important to note that there seems to be a process of harmonisation of safeguards across IFIs, often on the basis of the IFC's safeguards, the IFC Performance Standards (de Moerloose 2020). IFC's Performance Standards and Exclusion List are equally influential in the realm of bilateral development financing for the private sector through DFIs that are often majority or wholly owned by donor states as seen in the example of the Harmonized Environmental and Social Standards and Exclusion List of European Development Finance Institutions (EDFI) (EDFI 2020). Likewise, the Equator Principles, a framework for the management of environmental and social risks adopted by 113 financial institutions, such as BNP Paribas or JPMorgan Chase \& Co., in 37 countries to date, incorporate the IFC Performance Standards (Equator Principles 2020). The latter are therefore very influential, as, in addition to being a basis on which other IFIs harmonise, they are shared by financial institutions worldwide.

The procedural instruments for the integration of certain human rights and sustainable development concerns are the internal accountability mechanisms (IAM). Indeed, the implementation of the environmental and social safeguard can be reviewed by these IAMs, mostly in MDBs (Mbengue and de Moerloose 2018). In 1993, the WB became the first MDB to create an IAM, the Inspection Panel. All the other MDBs followed over the next years. IAMs have diverse proceedings and competences, and operate with different sets of environmental and social safeguards. However, broadly, they function in similar ways. Taking the WB as an example, after receiving a request by a party affected by a project, the Inspection Panel can review the compliance of the WB with its environmental and social safeguards with respect to the design, appraisal, implementation or supervision of a project (Bridgeman and Hunter 2008; Brunori 2019). A report may then be issued by the Inspection Panel. It is important to note that, generally, IAMs only statute on the noncompliance with the safeguards by the MDB and not by the recipient state. Furthermore, they cannot determine the consequence of a violation of the safeguards and 
have to transmit their findings to the Banks' respective authorities for their final decision. They have been qualified as 'quasi-judicial mechanism', as their competence and effectiveness for the redress of affected people's harm is limited (Tignino 2016).

\section{External Accountability}

External accountability of IFIs and their member states to human rights duty-bearers has been difficult to achieve.Yet, as Tan notes, focusing on internal accountability of IFIs without ensuring external accountability has the risk of reinforcing global power imbalances, by entrenching 'the normative authority of these institutions over countries in the Global South' but not delivering justice to rights-holder who find their rights violated (Tan 2019).

Accountability for ETOs in the context of IFIs may concern the activities and decisions of states as IFI members and shareholders. Khalfan (2017) argues that representatives voting on behalf of a single state or multiple states in IFIs would be 'responsible' (as in the ordinary sense of having responsibilities) to these states for their votes. Similarly, Barros (2019) finds that states as members of IFIs may and do maintain legislative supervision of their involvement in IFIs and what that involvement means in terms of their human rights obligations but that such supervisory practice is not exercised by all member states. Answerability to legislative or executive bodies of a state on behalf of which a representative is acting is not, as Alvarez underscores, the same as 'these institutions (or their executive boards or distinct major contributors to their respective budgets) [being] accountable to the poor or indigenous peoples affected by ... infrastructure projects or the macroeconomic conditions imposed under ... structural adjustment loans' (2016, p. 15). Additionally, external accountability also falls apart in the context of accountability of IFI member states (with strong decision-making power and influence) to rights-holders in third states. It is argued, for instance, based on ARIO, that votes cast by State representatives for or against individual policies or programmes cannot give rise to legal responsibility (Crawford 2014).

The central aspect of external accountability is direct accountability of IFIs to rights-holders. Yet, the 'broad (and often unlimited) immunities' that IFIs, in particular MDBs have enjoyed at the domestic level, 'have shielded the institutions from the reach of external accountability mechanisms' (Erdem Türkelli 2020, p. 258). The latest developments in the field with respect to direct external accountability of IFIs reflect the ongoing struggle to clarify the parameters of such accountability and the transformation of the law with respect to limiting IFI immunity. In 2015, a group of fishing communities and farmers from India sued the IFC in the United States District Court for the District of Columbia. The petitioners live near a coal-fired power plant, constructed with a $\$ 450$ million loan from the IFC to an Indian company. According to the complaint, the plant had polluted the air, landand water, destroyed the communities' livelihood and affected their health. The District Court held that the IFC enjoyed absolute immunity from suit. However, in Jam v. the IFC, the Supreme Court of the United States (SCOTUS) then held that IFC, as an IO, did not have absolute immunity from suit under US law given that some of its activities were commercial (SCOTUS 2019). The former Independent Expert on Debt and Human Rights also noted in his 2019 report that IFIs may be attributed legal responsibility for violations of human rights on the basis of complicity for imposing retrogressive economic measures, particularly in the context of austerity. The report underscores: 'There can be no legal justification for international financial institutions not to facilitate civil and political rights violations and to remain complicit in the imposition of economic, social and cultural rights violations' (UNGA 2019, para. 86). Still, on remand, the District Court upheld the immunity of IFC, deeming its nexus to the United States insufficient (Dias 2020). 


\section{Conclusions and future directions}

The gaps in human rights protection and accountability to rights-holders in the context of IFI macroeconomic or development policies or programmes and investment projects supported by IFIs require strengthening human rights beyond borders, both of states as members of IFIs and of IFIs as entities in their own right.

The differences between IFI member states in terms of their capabilities to influence the decision-making processes within IFIs of course arise from the differences in financial contributions and ownership. In addition, because any member state responsibility for IFI acts and omissions is viewed as exceptional, even major shareholding states with outsized influence within an institution are, as international law currently stands, not legally responsible for human rights violations resulting from IFI acts or omissions. The same states are also the home states of business enterprises that operate in host recipient countries backed by development financing that de-risks their investments. Power structures in the global economy determine to what extent and how states are able to impact the enjoyment of human rights, whether that is through IFI membership or through housing major multinational companies. Many recipient states where rights-holders impacted by IFI projects, programmes and policies are located are disadvantaged both in terms of how they are situated in the global economy generally and their positioning within IFIs. As the UN Secretary General António Guterres pointed out during his 2020 Mandela lecture, former colonised states, particularly in Africa, experience double exclusion as they are 'at greater risk of getting locked into the production of raw materials and low-tech goods' and are disadvantaged in terms of voting power and representation on the boards of international organisations, including Bretton Woods institutions (McVeigh 2020). Going forward, there is a need to address structural power dynamics underlying the global economy. This may mean that States' human rights obligations when they are members or 'owners' of IFIs need to be conceptualised as obligations shared by all states but differentiated by the measure of power accorded to each of those states in the globalised market economy as well as the historical underpinnings of these power structures. This may also demand for a reform of voting power in the IFIs, to remedy the power asymmetries.

'[IFI] decisions and performance are still often only measured against their own selfregulatory norms, which fall short of providing comprehensive rights protections to persons affected by such decisions and performance' (Erdem Türkelli 2020, p. 259). There are several policy measures that could provide for a better protection of human rights within IFI work. First, problems of noncompliance are often linked to the institutional organisation of the IFIs, particularly MDBs. In the case of the WB, the contradictory incentives for the staff include an accent on economic results versus compliance with environmental and social safeguards. The issues of noncompliance resulting from such organisational structures and incentives can only be reversed by institutional measures, which would demand that the Bank favours social and environmental sustainability and the respect of human rights above the pressures to commit and disburse funds. Secondly, it is important to also take into account the recipient state's context for the protection of rights within IFI activities: if the internal circumstances are not suitable for the protection of human rights, an investment project should be modified, postponed or dropped. Thirdly, problems of noncompliance are also linked to the fragmentation of environmental and social safeguards amongst IFIs. Safeguards are not yet harmonised despite a trend towards convergence. There are also clear difficulties for recipient states to implement conditionalities with which they are not familiar. Therefore, safeguards should be harmonised across IFIs and aligned with human rights in order to provide both legitimacy and a predictable framework (de Moerloose 2020, pp. 203-210). Fourthly, external accountability of IFIs and their more powerful 
member states to rights-holders, particularly in third states, should be strengthened by balancing the scales through enhanced due diligence obligations incumbent on these actors. The Guiding principles on human rights impacts assessments of economic policy reforms proposed by the former UN Independent Expert on Debt and Human Rights rightly places the 'burden of proof' on creditors (both states and IFIs) to 'demonstrate that their proposed economic reform measures will realize, and not undermine, States' human rights obligations'. According to the Guiding Principles, IFIs have 'a duty to carry out human rights impact assessments to evaluate and address any foreseeable effects of their economic policies on human rights' to be undertaken in consultation with rights-holders and made public 'in adequate formats' (Principle 13) (Bohoslavsky 2020, p. 1405).

The question of the immunity of IFIs also requires urgent reform to enable respect for and protection of human rights standards. Indeed, the terrible consequences for local population in the Jam v. IFC case cited above are hardly unique. Reading the findings of the IAMs suffices to show the detrimental impact that IFIs investments can have on local populations (Jokubauskaite 2018). Limiting the immunities of IFIs to allow for external oversight of their activities is a relevant response to the lack of accountability to rights-holders that characterises their operational landscape (Erdem Türkelli 2020). Because courts seem unwilling or unable to move past the immunity, the IFIs should modify their charters to restrict their immunity in case of human rights violations, or at least in case of violation of their own safeguards that amount to human rights violations. This is, in fine, the responsibility of Members states and would be a clear signal from IFIs that they are willing to 'do no harm' and also change internal incentives. A coherent and legally solid structural change would consist in both harmonising the safeguards by aligning them with human rights as well as limiting their immunity. Furthermore, the application of external accountability to all IFIs together with a human rights-based harmonisation would alleviate fears that more rigid safeguards adopted by a given IFI would allow another less rigorous IFI to attract clients and lead to an even more harmful outcome in terms of human rights (Erdem Türkelli 2020). Finally, when IFIs interact with rights-holders, their activities and policies are intertwined with multiple layers of other private actors such as financial intermediaries and business enterprises and conducted through private law arrangements (CESCR 2017; Bhatt 2020; Erdem Türkelli 2020). Without an adequate human rights legal regime that assigns human rights duties (beyond borders) to private actors in addition to states and IFIs, attempts at accountability of IFIs and their member states to rights-holders will always fall short of delivering their promise.

\section{Note}

1. Regarding the WBG, the chapter concentrates on three of its institutions: the International Bank for Reconstruction and Development, the International Development Association - both hereinafter collectively referred to as the World Bank or WB - and the International Finance Corporation (IFC).

\section{References}

African Development Bank Group (AfDB) (2013) Integrated Safeguards System, available at https://www.afdb.org/fileadmin/uploads/afdb/Documents/Policy-Documents/December_2013_-_ AfDB'S_Integrated_Safeguards_System____Policy_Statement_and_Operational_Safeguards.pdf. (accessed 16 July 2021).

Alvarez, J.E. (2016) 'International Organizations and the Rule of Law', New Zealand Journal of Public International Law 14(1), 3-46. 
Anghie, A. (2000) 'Time Present and Time Past', New York University Journal of International Law and Politics 32, 243-290.

Asian Development Bank (ADB) (2009) Safeguard Policy Statement, available at http://www.adb.org/ sites/default/files/institutional-document/32056/safeguard-policy-statement-june2009.pdf (accessed 16 July 2021).

Augenstein, D. (2014) 'The Crisis of International Human Rights Law in the Global Market Economy', Netherlands Yearbook of International Law 44, 41.

Babb, S. and Carruthers, B. (2008) 'Conditionality: Forms, Function, and History', Annual Review of Law and Social Science 4, 13-29.

Bantekas, I. and Lumina, C. (eds.). (2018) Sovereign Debt and Human Rights, Oxford University Press.

Barros A.S. (2019) Governance as Responsibility: Member States as Human Rights Protectors in International Financial Institutions, Cambridge University Press.

Bhatt, K. (2020) Concessionaires, Financiers and Communities: Implementing Indigenous Peoples' Rights to Land in Transnational Development Projects, Cambridge University Press.

Bohoslavsky, J.P. (2020) 'Guiding Principles on Human Rights Impacts Assessments of Economic Policy Reforms', The International Journal of Human Rights 24(9), 1400-1428.

Bohoslavsky, J.P. and Letnar Cernic, J. (eds.). (2014) Making Sovereign Financing and Human Rights Work, Hart. Bradlow, D.D. (1996) 'The World Bank, the IMF, and Human Rights', Transnational Law and Contemporary Problems 6(1), 47-90.

Bradlow, D.D. (2001) 'International Law and the Operations of International Financial Institutions' in Bradlow, D.D. and Hunter, D.B. (eds.). International Financial Institutions and International Law, Kluwer Law International.

Bridgeman, N.L. and Hunter, D.B. (2008) 'Narrowing the Accountability Gap: Toward a New Foreign Investor Accountability Mechanism', Georgetown International Environmental Law Review 20(2), 187-236.

Brunori, M. (2019) 'Protecting Access to Land for Indigenous and Non-Indigenous Communities: A New Page for the World Bank?', Leiden Journal of International Law 32(2), 1-16.

Channell, W. (2006) 'Lessons Not Learned about Legal Reform' in Carothers, T. (ed.). Promoting the Rule of Law Abroad, in Search of Knowledge, Carnegie Endowment for International Peace.

CNN (2010) 'BRIC leaders: IMF, World Bank has "legitimacy deficits", 16 April 2010, http://edition.cnn. com/2010/BUSINESS/04/15/bric.summit.brazil/index.html. (accessed 16 July 2021).

Crawford, J. (2014) State Responsibility, Cambridge University Press.

Dann, P. (2013) The Law of Development Cooperation, A Comparative Analysis of the World Bank, the EU and Germany, Cambridge University Press.

Dann, P. and Dollmaier, T. (2021) 'Multilateral Development Banks' in De Feyter, K. et al. (eds.). Encyclopedia of Law and Development, Edward Elgar.

de Moerloose, S. (2020) World Bank Environmental and Social Conditionality as a Vector of Sustainable Development, Schulthess Verlag.

De Schutter, O. (2012) 'The Role of Human Rights in Shaping International Regulatory Regimes', Social Research 79(4), 785.

De Schutter, O. et al. (2012) 'Commentary to the Maastricht Principles on Extraterritorial Obligations of States in the Area of Economic, Social and Cultural Rights', Human Rights Quarterly 34(4), 1084-1169.

Dias, S. (2020) 'Jam v. IFC before the D.C. District Court: Forget the Floodgates, there won't even be a Trickle', EJIL: Talk! -Blog of the European Journal of International Law, 1 April 2020, https://www. ejiltalk.org/jam-v-ifc-before-the-d-c-district-court-forget-the-floodgates-there-wont-even-be-atrickle/ [accessed 16 July 2021].

Dowell-Jones, M. and Kinley, D. (2011) 'Minding the Gap: Global Finance and Human Rights', Ethics and International Affairs 25(2), 183.

Dupuy, P.-M. and Kerbrat,Y. (2016) Droit International Public, 13th Ed., Dalloz.

Equator Principles, 'The Equator Principles', available at http://equator-principles.com/about (accessed 16 July 2021). 
Erdem Türkelli, G. (2020) 'The Best of Both Worlds or the Worst of Both Worlds? Multilateral Development Banks, Immunities and Accountability to Rights-Holders', Hague Journal on the Rule of Law 12, 251-281.

Escobar, A. (1995) Encountering Development, The Making and Unmaking of the Third World, Princeton University Press.

European Bank for Reconstruction and Development (EBRD) (2008) 'Environmental and Social Exclusion List', available at http://www.ebrd.com/downloads/about/sustainability/Environmental_and_ Social_Exclusion_and_Referral_Lists_15092008.pdf. (accessed 16 July 2021)

(2014) 'Environmental and Social Policy', available at http://www.ebrd.com/downloads/ research/policies/esp-final.pdf. (accessed 16 July 2021)

European Development Finance Institutions (2020) 'Policy', available at https://www.edfi.eu/policy/ (accessed 16 July 2021).

Evans, T. (2011) Human Rights in the Global Political Economy: Critical Processes, Lynne Rienner.

Henkin, L. (1999) 'That “S”Word: Sovereignty, And Globalization, And Human Rights, Et Cetera', Fordham Law Review 68, 1-14.

Himberg, H. (May 2015), 'Comparative Review of Multilateral Development Bank Safeguard Systems, Main Report and Annexes', available at https://consultations.worldbank.org/sites/default/files/consultation-template/review-and-update-world-bank-safeguard-policies/en/related/mdb_safeguard_comparison_main_report_and_annexes_may_2015.pdf. (accessed 16 July 2021)

Houghton, R. (2019) 'Looking at the World Bank's Safeguard Reform Through the Lens of Deliberative Democracy', Leiden Journal of International Law 32(2), 1-18.

Inter-American Development Bank (IADB) (n.d.) 'List of Excluded Activities for Non-Sovereign-Guaranteed (NSG) Operations', available at https://idbinvest.org/en/download/6392 (accessed 16 July 2021).

(n.d.) 'Operational Policies', available at https://www.iadb.org/en/about-us/operational-policies.(accessed 16 July 2021)

International Finance Corporation (IFC) (2012) 'Performance Standards on Environmental and Social Sustainability', available at https://www.ifc.org/wps/wcm/connect/Topics_Ext_Content/IFC_External_Corporate_Site/Sustainability-At-IFC/Policies-Standards/Performance-Standards (accessed 16 July 2021).

International Court of Justice (ICJ) (1980) Interpretation of the Agreement of 25 March 1951 between the WHO and Egypt, Advisory Opinion.

(1996) Legality of the Use by a State of Nuclear Weapon in Armed Conflict, Advisory Opinion.

Jokubauskaite, G. (2018) 'Tied affectedness? Grassroots resistance and the World Bank', Third World Thematics: A TWQ Journal 3(5-6), 703-724.

Kentikelenis, A. et al. (2016) 'IMF Conditionality and Development Policy Space, 1985-2014', Review of International Political Economy 23(4), 543.

Khalfan, A (2017) 'Development Cooperation and Extraterritorial Obligations' in Langford, M. and Russell, A. (eds). The Human Right to Water:Theory, Practice and Prospects, Cambridge University Press.

Killinger, S. (2003) The World Bank's Non-Political Mandate, Heymann.

Krajewski, M. (2014) 'Human Rights and Austerity Programmes' in Cottier.T. et al. (eds.). The Rule of Law in Monetary Affairs:World Trade Forum, Cambridge University Press.

Mbengue, M.M. and de Moerloose, S. (2017) 'Multilateral Development Banks and Sustainable Development: On Emulation, Fragmentation and a Common Law of Sustainable Development', Law and Development Review 10(2), 389-424.

(2018) 'A Managerial Approach for the Coherent Development of Sustainable Development Law: The Kenya Electricity Expansion Project before the World Bank and the European Investment Bank's International Accountability Mechanisms', Revista Jurídica Piélagus 17(2), 83-99.

McBeth, A. (2009) International Economic Actors and Human Rights, Routledge.

McInerney-Lankford, S. (2010) 'International Financial Institutions and Human Rights: Select Perspectives on Legal Obligations' in Bradlow, D.D. and Hunter, D.B. (eds.). International Financial Institutions and International Law, Kluwer Law International. 
McVeigh, K. (2020) 'UN chief slams 'myths, delusions and falsehoods' around inequality', The Guardian, 18 July 2020, https://www.theguardian.com/global-development/2020/jul/18/un-chief-slams-mythsdelusions-and-falsehoods-around-inequality (accessed 14 December 2020).

Mosley, P. et al. (1995) Aid and Power, the World Bank and Policy-based Lending, Volume 1, Analysis and policy proposals, $2^{\text {nd }}$ Ed., Routledge.

Naudé Fourie, A. (2009) The World Bank Inspection Panel and Quasi-Judicial Oversight, in Search of the 'Judicial Spirit' in Public International Law, Eleven International Publishing.

Nolan, A. (ed.). (2016) Economic and Social Rights after the Global Financial Crisis, Cambridge University Press.

Pahuja, S. (2011) Decolonising International Law: Development, Economic Growth and the Politics of Universality, Cambridge University Press.

Park, S. (2005), 'Norm Diffusion within International Organizations: A Case Study of the World Bank', Journal of International Relations and Development 8(2), 111-141.

Ryangaert, C. and Buchanan, H. (2011) 'Member State Responsibility for the Acts of International Organizations', Utrecht Law Review 7(1), 131-146.

Salomon, M. (2007) 'International Economic Governance and Human Rights Accountability' in Salomon, M. et al. (eds.). Casting the Net Wider: Human Rights, Development and New Duty-Bearers, Intersentia.

(2015) 'Of Austerity, Human Rights and International institutions', European Human Rights Journal 21(4), 521.

Sarooshi, D. (2005) International Organizations and their Exercise of Sovereign Powers, Oxford University Press.

Shihata, I.F.I. (1988-1989) 'The World Bank and Human Rights: An Analysis of the Legal Issues and the Record of Achievements', Denver Journal of International Law and Policy 17(39), 39-66.

Shihata, I.F.I. (1992) 'Human Rights, Development, and International Financial Institutions', American University International Law Review (1), 27-36.

Skogly, S. I. (2003) The Human Rights Obligations of the World Bank and the International Monetary Fund, Cavendish Publishing.

Stubbs, T. and Kentikelenis, A. (2018) 'Conditionality and Debt Relief: An Overview' in Bantekas, I. and Lumina, C. (eds). Sovereign Debt and Human Rights, Oxford University Press.

Supreme Court of the United States (SCOTUS) (2019) Budha Ismail Jam et al. v. International Finance Corp., 586 U.S.

Tan, C. (2008) "Mandating Rights and Limiting Mission Creep: Holding the World Bank and the International Monetary Fund Accountable for Human Rights Violations", Human Rights and International Legal Discourse 2(1), 79-116.

(2019) 'Human Rights and the Bretton Woods Institutions: Moving Beyond Institutional Remedies' in Bretton Woods Project, Bretton Woods at 75: a series of critical essays, Bretton Woods Project.

Tignino, M. (2016) 'Quasi-Judicial Bodies' in Brolmann, C. and Radl, Y. (eds.). Research Handbook on the Theory and Practice of International Lawmaking, Edward Elgar.

United Nations General Assembly (UNGA) (1947) Agreement between the United Nations and the International Bank for Reconstruction and Development, 16 U.N.T.S 346.

(1965) "Declaration on the Inadmissibility of Intervention in the Domestic Affairs of States and the Protection of Their Independence and Sovereignty" United Nations, Res. 2131 (XX), U.N. Doc. $\mathrm{A} / \mathrm{RES} / 2131$.

(1970) Declaration on Principles of International Law concerning Friendly Relations and Co-operation among States in accordance with the Charter of the United Nations, Res. 2625 (XXV), U.N.Doc.A/RES/2625.

(1981) Declaration on the Inadmissibility of Intervention and Interference in the Internal Affairs of States, Res. 36/103, U.N. Doc. A/RES/36/103.

(2019) Report of the Independent Expert on the effects of foreign debt and other related international financial obligations of States on the full enjoyment of all human rights, particularly economic, social and cultural rights: Responsibility for complicity of IFIs in human rights violations in the context of retrogressive economic reforms, A/74/178.

UN Committee on Economic, Social and Cultural Rights (CESCR) (1990a) GC 2 on International technical assistance measures (Art. 22 of the Covenant), E/1990/23. 
(1990b) GC 3 on the Nature of States Parties' Obligations (Art. 2, Para. 1, of the Covenant), E/1991/23.

(2000) GC 14 on the right to the highest attainable standard of health, E/C.12/2000/4.

(2002) GC 15 The Right to water, E/C.12/2002/11.

(2005) GC 18 The Right to Work, E/C.12/GC/18.

(2006) Convention on The Rights of Persons with Disabilities, UN Doc. A/RES/61/611.

(2017) GC 24 on State obligations under the International Covenant on Economic, Social and

Cultural Rights in the context of business activities, E/C.12/GC/24.

(2020) Statement on the coronavirus disease (COVID-19) pandemic and economic, social and cultural rights, E/C.12/2020/1.

UN Committee on the Rights of the Child (CRC Committee) (2013) GC 16 on State obligations regarding the impact of the business sector on children's rights, CRC/C/GC/16.

UN Human Rights Council (2011) UN Guiding Principles on Business and Human Rights (UNGPs) Implementing the United Nations "Protect, Respect and Remedy" Framework.

United Nations (UN) (1945) Charter of the United Nations and Statute of the International Court of Justice (24 November 1945).

United Nations Practitioners' Portal on Human Rights Based Approaches to Programming (n.d.) 'HRBA Portal, The Human Rights Based Approach to Development Cooperation:Towards a Common Understanding Among UN Agencies', available at https://hrbaportal.undg.org. (accessed 16 July 2021)

van Genugten, W. et al. (2003) World Bank, IMF and Human Rights, Wolf Legal Publishers, 2003.

von Bogdandy, A. et al. (eds). (2010) The Exercise of Public Authority by International Institutions: Advancing International Institutional Law, Springer.

Warwick, B. (2018) 'Debt, Austerity and the Structural Responses of Social Rights' in Bantekas, I. and Lumina, C. (eds). Sovereign Debt and Human Rights, Oxford University Press.

Woods, N. (2001) 'Making the IMF and the World Bank more accountable', International Affairs 77(1), $83-100$.

(2006) The Globalizers:The IMF, the World Bank, and Their Borrowers, Cornell University Press.

World Bank (2017) 'Environmental and Social Framework', available at https://www.worldbank.org/en/ projects-operations/environmental-and-social-framework 